\title{
Personalised Medicine for Tuberculosis and Non-Tuberculous Mycobacterial Pulmonary Disease
}

\author{
Kartik Kumar ${ }^{1,2}$ (D) and Onn Min Kon 1,2,*(D) \\ 1 National Heart and Lung Institute, Imperial College London, Dovehouse Street, London SW3 6LY, UK; \\ kartik.kumar@nhs.net \\ 2 Department of Respiratory Medicine, St Mary's Hospital, Imperial College Healthcare NHS Trust, \\ Praed Street, London W2 1NY, UK \\ * Correspondence: onn.kon@nhs.net
}

check for updates

Citation: Kumar, K.; Kon, O.M. Personalised Medicine for Tuberculosis and Non-Tuberculous Mycobacterial Pulmonary Disease. Microorganisms 2021, 9, 2220. https:// doi.org/10.3390/microorganisms9112220

Academic Editors: Isobella Honeyborne and Giovanni Satta

Received: 30 September 2021

Accepted: 25 October 2021

Published: 26 October 2021

Publisher's Note: MDPI stays neutral with regard to jurisdictional claims in published maps and institutional affiliations.

Copyright: (c) 2021 by the authors. Licensee MDPI, Basel, Switzerland. This article is an open access article distributed under the terms and conditions of the Creative Commons Attribution (CC BY) license (https:// creativecommons.org/licenses/by/ $4.0 /)$.

\begin{abstract}
Personalised medicine, in which clinical management is individualised to the genotypic and phenotypic data of patients, offers a promising means by which to enhance outcomes in the management of mycobacterial pulmonary infections. In this review, we provide an overview of how personalised medicine approaches may be utilised to identify patients at risk of developing tuberculosis (TB) or non-tuberculous mycobacterial pulmonary disease (NTM-PD), diagnose these conditions and guide effective treatment strategies. Despite recent technological and therapeutic advances, TB and NTM-PD remain challenging conditions to diagnose and treat. Studies have identified a range of genetic and immune factors that predispose patients to pulmonary mycobacterial infections. Molecular tests such as nucleic acid amplification assays and next generation sequencing provide a rapid means by which to identify mycobacterial isolates and their antibiotic resistance profiles, thus guiding selection of appropriate antimicrobials. Host-directed therapies and therapeutic drug monitoring offer ways of tailoring management to the clinical needs of patients at an individualised level. Biomarkers may hold promise in differentiating between latent and active TB, as well as in predicting mycobacterial disease progression and response to treatment.
\end{abstract}

Keywords: personalised medicine; tuberculosis; non-tuberculous mycobacteria; risk factors; nucleic acid amplification assays; next generation sequencing; host-directed therapies; therapeutic drug monitoring; biomarkers

\section{Background}

Mycobacterial lung diseases impose a significant healthcare and socioeconomic burden globally. In 2019, worldwide there were 7.1 million new diagnoses of tuberculosis (TB); 206,030 notified cases of rifampicin-resistant/multidrug-resistant (MDR) TB; 208,000 TB deaths among people living with human immunodeficiency virus (HIV) infection and 1.2 million deaths attributable to TB among HIV-negative people [1]. Non-tuberculous mycobacteria (NTM), which refer to all mycobacterial species other than Mycobacterium tuberculosis and $M$. leprae, may cause significant lung disease known as NTM pulmonary disease (NTM-PD). NTM-PD incidence rose from 3.13/100,000 to 4.73/100,000 between 2008 and 2015 in the USA and NTM infection incidence increased from 1.0/100,000 to 17.9/100,000 between 2003 and 2016 in the Republic of Korea, with the rises highest among females and older age groups [2,3]. While the human population is the reservoir of $M$. $t u$ berculosis in endemic countries and regions, NTM are ubiquitous environmental organisms. The incidence of NTM species varies in different regions, with a higher diversity found in humid and temperate climates [4]. Many challenges persist in the management of TB and NTM-PD [5,6]. Diagnosis is complex, requiring a combination of clinical, microbiological and radiological considerations $[7,8]$. Clinical symptoms may be non-specific, comprising any combination of breathlessness, cough, sputum production, haemoptysis, fever, night sweats, weight loss and fatigue. While culture-based techniques remain the mainstay of 
identifying mycobacterial isolates, they are associated with limitations, including the slow rate of growth of organisms and the potential for environmental contamination. TB and NTM-PD are also difficult to treat. Regimens are prolonged, associated with differing degrees of drug toxicity and success rates are variable, particularly in the treatment of drug-resistant isolates $[9,10]$.

Personalised medicine involves tailoring the provision of healthcare to patients according to their individual characteristics and profiles in order to prevent, diagnose and treat diseases. The Council of the European Union defines personalised medicine as a medical model in which a patient's genotypic and phenotypic data are utilised to determine their susceptibility to specified conditions, implement targeted strategies to prevent disease onset and tailor specific treatment regimens according to their needs [11]. Proponents of personalised medicine argue that it offers the benefits of enhancing prevention of disease; ensures that patients receive optimised, safer therapies that cater to their specific needs; and ultimately will improve the cost-effectiveness of healthcare services [12]. In recent years, attention has turned to the potential utility of adopting a personalised medicine approach to improve outcomes in patients with mycobacterial pulmonary infections.

In this review, we discuss the ways in which personalised medicine may be utilised in the management of mycobacterial lung disease. We provide an overview of how such approaches may be used to identify patients at risk of developing TB or NTM-PD, make a diagnosis of these conditions and guide effective therapeutic strategies (Figure 1). We also consider directions for future work in this field.

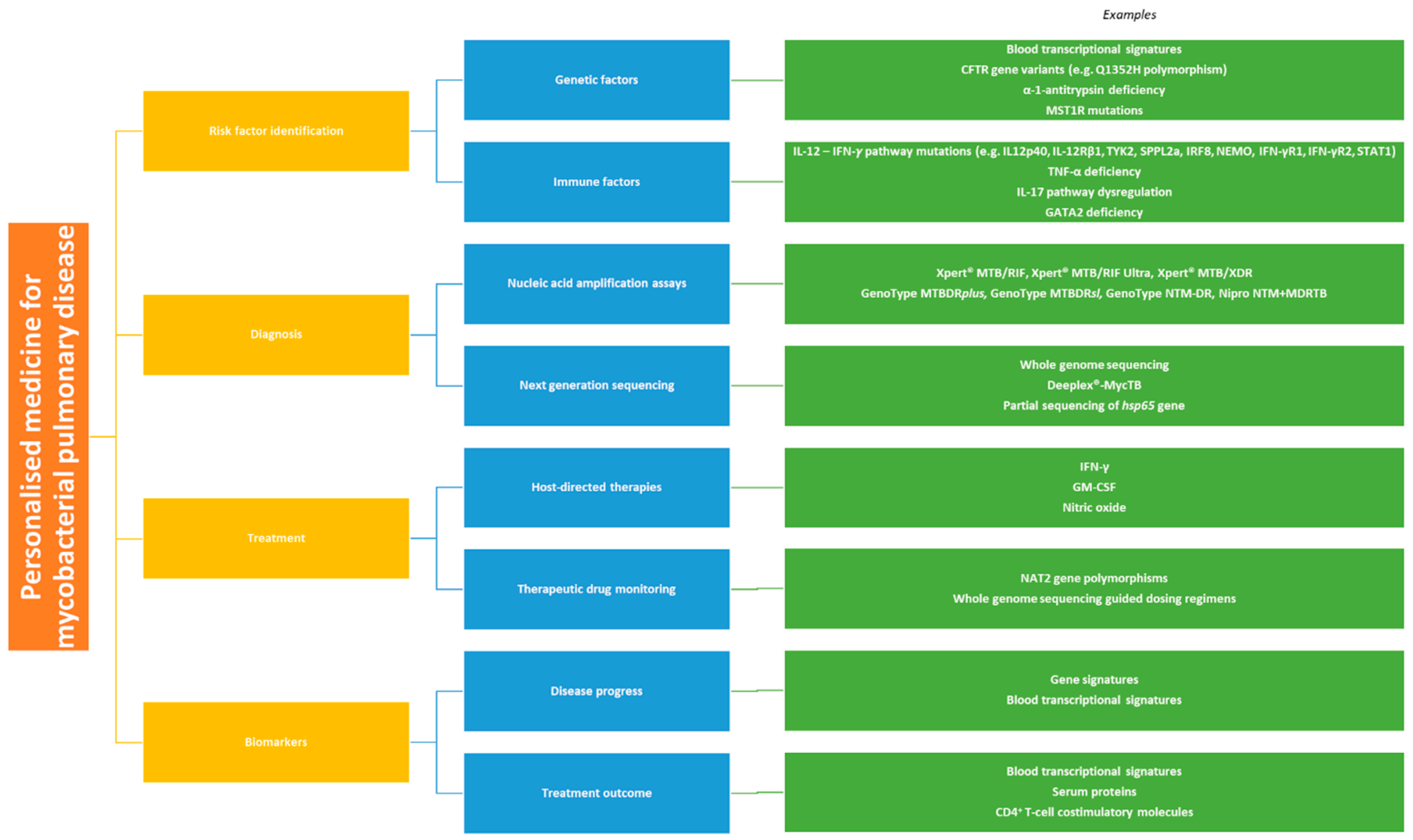

Figure 1. Personalised medicine approaches for the management of mycobacterial pulmonary disease.

\section{Identifying Risk Factors}

Determining who is at risk of developing of TB and NTM-PD is important so that such patients can be monitored for the development of clinically significant disease and early preventative measures can be instituted if necessary. 


\subsection{Genetic Factors}

Genome-wide association studies have identified susceptibility and protective loci for TB. In a study that combined two genome-wide association studies in populations from Ghana and The Gambia, a single nucleotide polymorphism on chromosome 18q11.2 was associated with susceptibility to TB (odds ratio (OR) 1.19, combined $P=6.8 \times 10^{-9}$, $95 \%$ confidence interval (CI) 1.13-2.27) [13]. These findings however were not replicated in a meta-analysis of four studies in Chinese populations [14]. In a study in a Han Chinese population, an increased risk of TB was associated with single nucleotide polymorphisms on 14q24.3 (OR 1.277, combined $p=1.72 \times 10^{-11}$ ) and 20p13 (OR 1.339, combined $p=2.37 \times 10^{-11}$ ) [15]. Loci protective against TB have been identified on 11p13 [16,17]. Furthermore, in a recent study in a Vietnamese population comprising household contacts of pulmonary TB, a locus on 10q26.2 was found to be associated with protection against TB and the findings were replicated in cohorts from France and South Africa [18].

Transcriptomic studies of TB infection risk have yielded variable results. In a study of patients in Uganda, transcriptional profile analysis demonstrated that monocytes derived from patients with apparent resistance to TB infection differentially activated pathways controlled by histone deacetylases in response to $M$. tuberculosis exposure [19]. In a paediatric population in a high-incidence setting, a 51-transcript signature was shown to have a sensitivity of $82.9 \%$ and specificity of $83.6 \%$ for distinguishing between TB and other diseases [20]. In an adult population in a high-incidence setting, a 44-transcript signature was used to calculate a disease risk score for patients which was found to differentiate between active TB and other diseases with a sensitivity of $93 \%$ and specificity of $88 \%$ [21]. In a prospective study from a low-incidence setting, the highest performing transcriptomic signature indicative of active TB had both a sensitivity and specificity of $77 \%$, which was insufficient to meet World Health Organisation (WHO) diagnostic cut-offs for non-sputum tests for smear-negative TB [22].

There is an increased risk of NTM-PD among patients with cystic fibrosis (CF). Several CF transmembrane conductance regulator (CFTR) variants have been shown to occur at a higher frequency among patients with bronchiectasis or NTM-PD than among healthy controls [23]. One prospective study found that $36 \%$ of NTM-PD patients had CFTR mutations [24]. In another study investigating familial clustering of NTM-PD, five out of 12 patients with NTM-PD secondary to various NTM species were found to have CFTR gene variants but did not have classic CF [25]. The Q1352H polymorphism of the CFTR gene has been found to occur at a higher frequency among patients with NTM-PD than among controls (OR 4.27, 95\% CI 1.43-12.78) [26]. CFTR mutations have been associated with changes in DNA methylation in lung macrophages [27], increased macrophage apoptosis and decreased phagocytosis [28], all of which may contribute to immune dysregulation and thus increased NTM infection risk.

$\alpha-1$-antitrypsin (AAT) deficiency may predispose to mycobacterial lung disease by decreasing phagosome-lysosome fusion in macrophages, thereby decreasing mycobacterial clearance [29]. Anomalies in AAT protein were found in 27\% of patients with NTM-PD secondary to rapid-growing NTM species, which was 1.6 times higher than would be expected in the general population [30]. Pulmonary alveolar proteinosis, characterised by protein accumulation in alveoli due to defective surfactant clearance by macrophages, has also been shown to be associated with increased risk of mycobacterial infection [31,32].

Single nucleotide polymorphisms in the region of the class II human leucocyte antigen (HLA) have been shown to confer increased risk of TB infection or disease: examples include rs557011[T] and rs9271378[G], located between HLA-DQA1 and HLA-DRB1; and a missense variant (p.Ala210Thr) in HLA-DQA1 [33]. Studies on vitamin D receptor (VDR) polymorphisms and mycobacterial infection risk have yielded variable results. While one meta-analysis was inconclusive [34], a more recent analysis found that the VDR gene FokI polymorphism confers increased risk of TB, particularly among patients who are HIV-negative or Asian, but not among those who are African or Caucasian [35]. VDR polymorphisms have been associated with $M$. malmoense lung disease [36]. In a larger 
study however VDR TaqI and FokI polymorphisms were not found to be associated with NTM-PD susceptibility [37].

The odds of polymorphisms in the natural-resistance-associated macrophage protein 1 gene have been shown to be higher among patients with NTM-PD than non-NTM controls, although no significant differences were found in polymorphism frequency between patients with $M$. avium complex (MAC) pulmonary disease (MAC-PD) and M. abscessus (MAB) pulmonary disease (MAB-PD) [38]. Mutations in the macrophage-stimulating-1 receptor (MST1R) gene have been implicated in the development of "Lady Windermere syndrome", in which NTM-PD occurs in patients who have a slender body habitus, pectus excavatum and scoliosis [39]. Activation of MST1R, a tyrosine kinase receptor on airway epithelial cells, is associated with increased ciliary function and it has been postulated that MST1R gene mutations may diminish ciliary clearance of NTM $[39,40]$.

\subsection{Immune Impairment}

The interleukin-12 (IL-12) - interferon- $\gamma$ (IFN- $\gamma$ ) pathway plays a pivotal role in immunity against mycobacterial disease. Mendelian susceptibility to mycobacterial disease arises due to mutations in this pathway: decreased IFN- $\gamma$ production has been attributed to mutations in genes encoding IL12p40, IL-12Rß1, TYK2 (a Janus kinase), SPPL2a (a protease), IRF8 and NEMO; whilst diminished response to IFN- $\gamma$ has been attributed to mutations in genes encoding IFN- $\gamma$ R1, IFN- $\gamma$ R2, STAT1, IRF8 and NEMO [41]. A study evaluating cytokine production by peripheral blood mononuclear cells (PBMCs) found that IFN- $\gamma$, tumour necrosis factor- $\alpha$ (TNF- $\alpha$ ) and IL-12 production was significantly lower in patients with NTM-PD compared to non-NTM controls [42]. A whole-blood gene expression study has shown that patients with NTM-PD exhibit reduced expression of transcripts such as IFNG and others involved in T-cell signalling compared to non-NTM controls [43]. Reduced IFNG was associated with more marked radiographic changes and altered lung function [43]. Notably polymorphisms in certain genes may be associated with one type of mycobacterial infection but not others. IL-12R $\beta 1$ gene polymorphisms were associated with increased risk of pulmonary TB in a study in Morocco but were not associated with susceptibility to NTM-PD in a Korean population [44,45].

Deficiency in production of TNF- $\alpha$, another important cytokine in antimycobacterial defence which acts via macrophage activation [46], has been associated with mycobacterial lung disease. In a study of patients with $\mathrm{CF}$, the number of TNF- $\alpha$-producing $\mathrm{CD} 4^{+} \mathrm{T}$-cells was significantly lower among patients with current or previous MAB-PD compared to healthy controls [47]. Patients with MAC-PD have been found to exhibit diminished PBMC production of TNF- $\alpha$ compared to healthy controls [48]. Impaired IL-17 responses have been reported in patients with MAC-PD [49] and MAB-PD [50], while transcriptional studies have demonstrated that downstream targets of the IL-17 pathway appear to be upregulated in NTM-PD even though IL-17 itself is not [51]. Exaggerated IL-17A and Th17 responses however have been observed in active TB compared to latent TB infection (LTBI) [52].

Deficiencies in GATA2, a zinc finger transcription factor, are associated with a spectrum of haematological abnormalities such as monocytopaenia, lymphopoenias, leukaemias and susceptibility to fungal, viral and mycobacterial infections [53]. Such patients are particularly at risk of MAC infections [54].

\section{Diagnosis}

A diagnosis of TB hinges on microbiological techniques. Diagnosing NTM-PD is contingent upon consideration of patient factors, culture or PCR-based microbiology and imaging [55], as recommended by clinical guidelines [8]. Correctly identifying mycobacterial isolates and their antibiotic susceptibility is an important step in the management of mycobacterial lung disease. Phenotypic drug susceptibility testing (DST) involving culture-based techniques are widely used but their limitations include the risk of culture contamination and the time taken to yield final results. Molecular tests offer a more rapid 
means to establish the resistance profiles of isolates, guide the appropriate selection of antibiotics and identify transmission of isolates, with the latter being particularly important for TB outbreak control and follow up of contacts [56].

\subsection{Nucleic Acid Amplification Assays}

The Xpert $^{\circledR}$ MTB/RIF (Cepheid, Sunnyvale, CA, USA) is a nucleic acid amplification assay that utilises real-time polymerase chain reaction (PCR) to detect $M$. tuberculosis complex as well as mutations in the $r p o B$ gene [57], which confer M. tuberculosis isolates with rifampicin resistance [58]. The newer Xpert ${ }^{\circledR}$ MTB/RIF Ultra (Cepheid, Sunnyvale, CA, USA) improves upon the sensitivity of the Xpert ${ }^{\circledR}$ MTB/RIF assay by utilising two different amplification targets and having an improved cartridge design (Table 1) $[59,60]$. Xpert ${ }^{\circledR}$ MTB/RIF Ultra and Xpert ${ }^{\circledR}$ MTB/RIF have a similar sensitivity (94.9\% vs. $95.3 \%$, respectively) and specificity (99.1\% vs. 98.8\%) for detecting rifampicin resistance [61]. The recently developed Xpert ${ }^{\circledR}$ MTB/XDR (Cepheid, Sunnyvale, CA, USA), capable of identifying 16 resistance-conferring mutations in M. tuberculosis (Table 1) [62], has been shown to have a high sensitivity (94.1-100\%) and specificity (100\%) for detecting resistance to isoniazid, fluoroquinolones and second-line injectable drugs; the sensitivity and specificity for detecting ethionamide resistance was slightly lower $(88.5 \%$ and $97.3 \%$, respectively) [63]. Another study has shown that the assay is capable of detecting 100\% of the tested mutations for resistance to these drugs but has more variable outcomes for detecting heteroresistance [64].

Table 1. Nucleic acid amplification tests for detecting resistance in M. tuberculosis isolates $[59,60,62]$.

\begin{tabular}{|c|c|c|}
\hline Nucleic Acid Amplification Test & Antibiotic Resistance Detected & Corresponding Mutations \\
\hline Xpert $^{\circledR}$ MTB/RIF & \multirow{2}{*}{ Rifampicin } & \multirow{2}{*}{$r p o B$} \\
\hline Xpert $^{\circledR}$ MTB/RIF Ultra & & \\
\hline Xpert $^{\circledR}$ MTB/XDR & $\begin{array}{c}\text { Isoniazid } \\
\text { Ethionamide } \\
\text { Fluoroquinolones } \\
\text { Second-line injectable drugs }\end{array}$ & $\begin{array}{c}\text { katG, fabG1, oxyR-ahpC intergenic region, inhA promoter } \\
\text { inhA promoter } \\
\text { gyrA and gyrB quinolone resistance determining regions } \\
r r s, \text { eis promoter }\end{array}$ \\
\hline
\end{tabular}

Line probe assays (LPAs) are DNA-DNA hybridisation assays that enable rapid detection of $M$. tuberculosis isolates and detection of multiple mutations, including in the rpoB, kat $G$ and inhA genes (Table 2) [65]. WHO endorses the use of first-line LPAs such as GenoType MTBDRplus (Hain Lifescience, Nehren, Germany) [66] and Nipro NTM+MDRTB (Nipro, Osaka, Japan) [67] to detect resistance to rifampicin and isoniazid; and the use of second-line LPAs such as GenoType MTBDRsl (Hain Lifescience, Nehren, Germany) to detect mutations in $g y r A, g y r B, e m b B$, rrs and eis genes that confer resistance to fluoroquinolones, ethambutol and second-line injectable agents [1]. A meta-analysis has demonstrated that GenoType MTBDRplusV1, GenoType MTBDRplusV2 and Nipro NTM+MDRTB have a high pooled sensitivity (96.7\%) and specificity $(98.8 \%)$ for rifampicin resistance; and slightly lower sensitivity (90.2\%) but high specificity (99.2\%) for isoniazid resistance [68]. In a high MDR TB incidence setting, GenoType MTBDRsl was found to detect resistance with a sensitivity of $73.6 \%$ for fluoroquinolones, $64.7 \%$ for ethambutol, $20 \%$ for kanamycin, $25 \%$ for amikacin and $100 \%$ for capreomycin [69]. Moreover the sensitivity and specificity of GenoType MTBDRsl VER 2.0 was high for fluoroquinolone resistance but more variable for resistance to second-line injectable drugs [70]. It should be noted that molecular DSTs such as Xpert ${ }^{\circledR}$ MTB/RIF and GenoType MTBDRplus may miss certain mutations in the $r p o B$ gene, such as the Ile49Phe variant seen in MDR TB in South Africa, which runs the risk of ineffective drug regimens being prescribed and further spread of infection [71]. 
Table 2. Line probe assays for detecting resistance in mycobacterial isolates $[66,67,72]$.

\begin{tabular}{|c|c|c|c|}
\hline Line Probe Assay & Mycobacterial Isolates Detected & Antibiotic Resistance Detected & Corresponding Mutations \\
\hline GenoType MTBDRplus VER 2.0 & & $\begin{array}{l}\text { Rifampicin } \\
\text { Isoniazid }\end{array}$ & $\begin{array}{c}r p o B \\
k a t G, \text { inh } A \text { promoter }\end{array}$ \\
\hline GenoType MTBDRsl VER 1.0 & M. tuberculosis & $\begin{array}{c}\text { Ethambutol } \\
\text { Fluoroquinolones } \\
\text { Second-line injectable drugs }\end{array}$ & $\begin{array}{l}e m b B \\
g y r A \\
r r s\end{array}$ \\
\hline GenoType MTBDRsl VER 2.0 & & $\begin{array}{l}\text { Fluoroquinolones } \\
\text { Second-line injectable drugs }\end{array}$ & $\begin{array}{l}\text { gyrA, gyrB } \\
\text { rrs, eis }\end{array}$ \\
\hline Nipro NTM+MDRTB detection kit 2 & $\begin{array}{l}\text { M. tuberculosis complex and } \\
\text { differentiates } M . \text { avium, } M \text {. } \\
\text { intracellulare } \mathcal{E} \text { M. kansasii }\end{array}$ & $\begin{array}{l}\text { Rifampicin } \\
\text { Isoniazid }\end{array}$ & $\begin{array}{c}\text { rpoB } \\
\text { katG, inh } A\end{array}$ \\
\hline GenoType NTM-DR & NTM & $\begin{array}{c}\text { Macrolides } \\
\text { Aminoglycosides }\end{array}$ & $\begin{array}{c}r r l, e r m(41) \\
r r s\end{array}$ \\
\hline
\end{tabular}

The GenoType NTM-DR assay (Hain Lifescience, Nehren, Germany) [72] has been shown to accurately identify $100 \%$ of MAB isolates and $92.1 \%$ of MAC isolates, with certain strains of the latter being misidentified as M. intracellulare [73]. The same study demonstrated that GenoType NTM-DR exhibited $96.3 \%$ sensitivity and 100\% specificity in detecting clarithromycin resistance; with $99.3 \%$ concordance with sequencing and $98.6 \%$ concordance with DST [73]. Additionally, the assay detected amikacin resistance with $62.5 \%$ sensitivity and $100 \%$ specificity; with $99.3 \%$ concordance with sequencing and $97.9 \%$ concordance with DST [73]. More recently, the GenoType NTM-DR assay was found to have $100 \%$ concordance with multi-locus sequence typing in identifying MAB subspecies; and $100 \%$ concordance with DST for detecting resistance to clarithromycin and amikacin [74].

\subsection{Next Generation Sequencing (NGS)}

Recently there has been an increasing shift towards investigating and establishing genotypic DST for mycobacterial disease. Advances in NGS techniques have expedited the diagnosis of mycobacterial infections. Whole genome sequencing (WGS) enables rapid identification of mycobacterial isolates and their drug susceptibility or resistance profiles, whilst also facilitating epidemiological investigations of outbreaks [75]. WGS has been shown to identify mycobacterial species with $93 \%$ accuracy, identify drug susceptibility with $93 \%$ accuracy, link isolates to outbreaks and incur $7 \%$ lower costs annually compared to routine diagnostic techniques [76]. A recent study has shown that WGS of M. tuberculosis DNA acquired directly from sputum was able to yield isolate resistance data up to 24 days faster than WGS of isolates cultured in a Mycobacterial Growth Indicator Tube (MGIT) and up to 31 days faster than phenotypic testing of isolates [77]. The Deeplex ${ }^{\circledR}$-MycTB deep sequencing assay (Genoscreen, Lille, France) enables genotyping of M. tuberculosis isolates and covers 18 sequencing regions that are associated with drug resistance. It has been shown to have high concordance with phenotypic DST for first line drugs rifampicin $(97.4 \%)$, isoniazid $(94.9 \%)$, pyrazinamide $(97.4 \%)$ and ethambutol $(97.4 \%)$; and second line drugs including fluoroquinolones $(66.7 \%)$, prothionamide $(75.0 \%)$, aminoglycosides $(100 \%)$, linezolid (100\%) and bedaquiline (100\%) [78].

There have been substantial advances in the genomic characterisation of previously uncharacterised NTM species in recent years due to the availability of WGS [79]. The use of WGS identified possible transmission of M. abscessus subsp. massiliense between patients with CF in a UK centre [80], but it has also been useful in refuting potential transmission of isolates between close contacts [81]. A recent study has found that there is limited concordance between WGS analysis and LPAs in the identification of mixed NTM infections [82]. Partial sequencing of the 16S rRNA gene may be insufficient to identify different NTM species [83]. Notably however partial sequencing of the $h s p 65$ gene from the sputum of patients with NTM-PD has been shown to identify a median 5.5 NTM species per sample compared to up to one species identified by culture-based techniques 
alone, implying a more diverse community of NTM species is present in the lungs than culture-based techniques would suggest [84].

\section{Treatment}

\subsection{Host-Directed Therapies}

Treatment regimens for mycobacterial infection can be tailored to address the individual clinical needs of patients according to their risk factors, comorbidities and severity of disease. One approach may be to treat specific underlying immunological deficiencies. In a case report on a patient with functional IFN- $\gamma$ deficiency and NTM-PD, administration of nebulised IFN- $\gamma 1 \mathrm{~b}$ resulted in improved NTM clearance and stabilisation of lung function [85]. In another patient with a homozygous mutation in the IFN $\gamma$ R1 gene and disseminated M. avium disease, administration of subcutaneous IFN- $\gamma$ was associated with disease control and eventual regression of cerebral lesions [86]. A previous metaanalysis has demonstrated that adjunctive aerolised and intramuscular IFN- $\gamma$ can improve sputum culture conversion at different time points during the course of pulmonary TB treatment [87].

In patients with disseminated NTM disease on a background of having confirmed antiIFN- $\gamma$ autoantibodies, administration of rituximab, a monoclonal antibody targeting CD20 on $\mathrm{B}$ cells, has been shown to reduce both the autoantibody titres and their neutralising capacity against IFN- $\gamma$; and result in clinical improvement $[88,89]$. The use of intravenous cyclophosphamide in patients with anti-IFN- $\gamma$ autoantibodies and refractory MAB infection has had mixed outcomes [90].

Based on the hypothesis that activation of the granulocyte-macrophage colony-stimulating factor (GM-CSF) receptor enhances macrophage activation, which may be reduced in patients with $\mathrm{CF}$, a case report has described how administration of inhaled GM-CSF in patients with $\mathrm{CF}$ and MAB-PD was associated with clinical, microbiological and radiological improvement [91]. A clinical trial found that administration of adjunctive GM-CSF in the treatment of pulmonary TB trended towards, but did not significantly enhance, sputum culture conversion at week eight of treatment [92].

Various other novel treatments have been trialled in patients with severe mycobacterial disease who have not responded to conventional therapies. A recent pilot study demonstrated that intermittent inhaled nitric oxide administration in patients with CF and refractory MAB-PD resulted in improvement in six-minute walk distance and forced expiratory volume in one second, building on the premise that higher levels of nitric oxide in CF airways are associated with improved lung function [93]. Engineered bacteriophage therapy in a patient with $\mathrm{CF}$ and disseminated drug-resistant $M$. abscessus infection was recently found to result in improvement in pulmonary function, liver function and dermatological lesions [94]. A range of other host-directed therapeutic strategies have been described for TB and NTM-PD, including targeting various components of the adaptive and innate immune responses [95-97].

\subsection{Therapeutic Drug Monitoring (TDM)}

TDM refers to the process by which medication doses are tailored to individual patients based on the drug's blood or plasma concentration at specified times, such that the drug level is maintained within a therapeutic window that is both safe and efficacious for the patient [98]. This is important in the treatment of mycobacterial infection because inadequate dosing or drug levels that are outside the desired therapeutic window can be linked to treatment failure, drug toxicity or the emergence of drug-resistant isolates [99]. Rifampicin levels are commonly measured in clinical practice. Slow responders to TB therapy have been shown to have two-hour post-dose rifampicin levels that are below the expected range and TDM can be used to direct dose adjustment to achieve therapeutic drug levels [100].

In a study evaluating the effect of adjusting the dose of isoniazid in patients with newly diagnosed pulmonary TB according to the extent of the patients' $\mathrm{N}$-acetyltransferase 
2 (NAT2) gene polymorphisms, slow acetylators receiving tailored dosing did not incur any isoniazid-induced hepatotoxicity or treatment failure; and there was a lower rate of early treatment failure among rapid acetylators receiving tailored dosing [101]. A recently developed pharmacogenomic assay has been shown to accurately detect NAT2 gene allele patterns in pulmonary TB patients and may be of use in guiding isoniazid dosing [102]. The feasibility and effect on sputum conversion rates of TDM for fluoroquinolones, which are used in the treatment of drug-resistant TB [103], is currently under investigation [104].

TDM has been used to direct dosing of drugs that have relatively narrow therapeutic windows. A retrospective evaluation in the Netherlands found that TDM-guided low doses of amikacin and kanamycin were associated with a reduced rate of ototoxicity whilst maintaining efficacy when treating MDR TB [105]. These findings were supported in a recent study in Canada in which there were low rates of ototoxicity and nephrotoxicity associated with TDM-guided low-dose amikacin in patients with MDR TB [106]. TDM has also been used to lower the dose of linezolid administered in select MDR TB patients, although the efficacy of doing so remains to be seen [107]. In settings where monitoring plasma levels of drugs may not be feasible due to resource constraints, dried blood spot (DBS) sampling may offer a practical solution. Such specimens have been shown to exhibit good concordance with conventional plasma level monitoring in TDM of linezolid when treating MDR TB [108]. DBS sampling has also been successfully used for TDM of other drugs such as rifampicin and clarithromycin [109]. Samples can be sent by post at ambient temperatures to remote reference laboratories, enabling drug doses to be tailored for patients in settings where healthcare resources may be limited [99]. Dose adjustments based on TDM combined with phenotypic or genetic DST can facilitate improved efficacy while reducing toxicity substantially in drugs that have narrow therapeutic windows.

WGS of mycobacterial isolates may hold potential in guiding dosing regimens. It has been used to quantify the degree of drug resistance that would be expected to occur for various drug resistance mutations [110]. A study on drug-resistant $M$. tuberculosis isolates in Romania identified that drug minimum inhibitory concentrations (MICs) were affected by the nature of the resistance mutation in the isolate: high MICs were associated with the rpoB S450L mutation for rifampicin and the kat G S315T mutation for isoniazid [111]. DST based on WGS of drug-resistant $M$. tuberculosis isolates has demonstrated that different resistance-conferring mutations are associated with differences in MICs: for example, the MIC for isoniazid is significantly lower in isolates with the $-15 \mathrm{c} / \mathrm{t}$ inh $A$ promoter mutation than in isolates with the katG Ser315Thr mutation [112].

\section{Biomarkers}

Identifying biomarkers that are able to differentiate LTBI from TB and that can predict disease progression or therapeutic success will provide clinicians with prompt insights into how to manage patients with mycobacterial lung disease.

\subsection{Distinguishing LTBI from Active TB Disease}

Gene expression signatures indicative of LTBI are yet to be identified [113]. A recent cytokine analysis demonstrated that eotaxin, macrophage-derived chemokine and monocyte chemoattractant protein- 1 were together able to differentiate between active and latent TB with a sensitivity of $87.8 \%$ and specificity $91.8 \%$ [114]. In patients who are IFN- $\gamma$ release assay (IGRA) positive but acid-fast bacilli negative, signatures of HLA-DR ${ }^{+} \mathrm{IFN}-\gamma^{+} \mathrm{CD} 4^{+} \mathrm{T}$ cells and CD45RA ${ }^{-}$CCR7-CD127-IFN- $\gamma^{-}$IL-2-TNF- $\alpha^{+} \mathrm{CD}^{+}{ }^{+}$T-cells were able to distinguish between active TB and LTBI [115]. A whole blood gene signature comprising the genes GBP5, DUSP3 and KLF2 has been shown to distinguish between LTBI and active TB in a multicohort analysis [116]. Furthermore various transcriptomic signatures that distinguish between latent and active disease in high-incidence settings have been reported [20,21]. Recently however in a whole blood microarray analysis of TB patients in a low-incidence setting, transcriptomic signatures were not found to be sufficiently sensitive or specific 
to diagnose TB [22]. Additionally, a review has found that the diagnostic accuracy of previously published transcriptomic signatures for TB was lower than reported [117].

\subsection{Predictors of Disease Progression}

Prospective studies have identified unique gene and transcriptomic signatures predictive of TB progression. In a study of adolescents infected with $M$. tuberculosis, a 16 gene signature was shown to identify risk of TB progression with a sensitivity of $66.1 \%$ and specificity of $80.6 \%$ in the year preceding TB diagnosis [118]. More recently whole blood transcriptomic and proteomic analyses have demonstrated increased type I/II IFN signalling 18 months preceding TB diagnosis and suppression of Th17 responses in patients progressing from infection to active pulmonary disease [119].

\subsection{Predictors of Treatment Outcome}

A blood transcriptional signature for active TB that correlates with radiological changes has previously been described and shown to change to that of healthy controls following TB treatment [120]. Blood transcriptional signatures for active TB and treatment response have been shown to attenuate over the course of treatment, particularly following the initial two weeks of treatment [121]. Various other biomarkers of TB treatment response have been identified, including serum proteins such as C-reactive protein, IL-1 $\beta$, IL-6, matrix metalloproteinase-8 (MMP-8), procalcitonin, pentraxin 3 and serum amyloid A1, all of which were strongly associated with baseline TB severity and modulated by TB treatment [122]. A range of costimulatory molecules in CD4+ T-cells have been implicated in active TB and suggested as being useful for monitoring response to treatment. Active $\mathrm{TB}$ has been associated with a $\mathrm{CD} 38^{\text {positive }} \mathrm{CD} 27^{\text {low }} \mathrm{CD} 4^{+} \mathrm{T}$-cell phenotype, treated $\mathrm{TB}$ with a $\mathrm{CD} 38^{\text {negative }} \mathrm{CD} 27^{\text {low }}$ phenotype and latent $\mathrm{TB}$ with a $\mathrm{CD} 38^{\text {negative }} \mathrm{CD} 27^{\text {high }}$ phenotype [123]. Persistent culture positivity has been associated with serum RANTES level at the time of diagnosis and MMP-8 levels following two months of treatment [124]. Urinary lipoarabinomannan (LAM), which has been shown to reduce 8-week mortality when it is used to guide initiation of anti-TB therapy in patients with HIV infection and suspected TB [125], may also have a role in monitoring treatment response. Among patients with culture-confirmed pulmonary TB in a high-incidence setting, a strongly positive urinary LAM following two months of intensive therapy was found to be associated with a significantly higher risk of mortality during three-year follow-up than a weakly positive or negative urinary LAM result [126].

Microbiological biomarkers of treatment response in macrolide-susceptible MACPD may include the time to positivity (TTP) for MGIT culture systems, with one recent retrospective study identifying that a TTP of greater than seven days at baseline and a TTP of greater than 15 days following three months of treatment were predictive of sputum culture conversion within the initial six months of therapy [127]. Potential blood biomarkers of treatment response in MAC-PD include a decrease in serum anti-glycopeptidolipid IgA levels following treatment; a worsening in radiographic changes has been observed in those patients in whom antibody levels rose following treatment cessation [128]. Th1related cytokine levels have been shown to be reduced at the time of MAC-PD diagnosis but improve following 12 months of treatment, while Th-17 related cytokines have been associated with failure of sputum conversion [129]. Moreover four differentially expressed serum miRNAs implicated in host immune response have recently been identified as being expressed at higher levels among NTM-PD patients than healthy controls, earmarking these as additional potential biomarkers for diagnosis and treatment response [130].

Biomarkers capable of reliably guiding an individualised duration of anti-mycobacterial therapy are needed, particularly in the treatment of drug-resistant isolates. This is important as a 'one size fits all' approach to treatment length runs the risk of many patients being exposed to the toxicity of therapy for longer than may be clinically needed. Notably a whole blood transcriptomic model evaluated in cohorts in Germany and Romania has recently been shown to predict the duration of treatment required in patients with TB; and found that cure 
could be achieved in most patients with MDR TB using a shorter treatment duration [131]. Any approaches to individualise duration of therapy will require validation in large cohorts of patients.

\section{Future Priorities}

In recent years, there have been significant advances in the development personalised medicine approaches to identify those at risk of mycobacterial lung disease, obtain a definitive diagnosis and tailor therapies to meet individual patients' needs. There remain however a number of challenges if such approaches are to have a meaningful impact on the clinical management of TB and NTM-PD globally. Widespread implementation of personalised medicine will be contingent upon having the prerequisite infrastructure in place, which may be particularly difficult in resource-limited settings; although as illustrated by the use of DBS in TDM, novel solutions may be found. Investment will be needed both in health technologies and training of staff for effective scale up to be achieved, requiring political buy-in and visionary leadership from health policymakers.

Further clinical studies and trials are needed to establish reliable biomarkers that not only indicate increased host susceptibility to mycobacteria, but also are able to distinguish between innocuous colonisation, infection and active disease; discriminate between mild and more severe disease courses; predict treatment response and duration; and predict the likelihood of future relapse or reinfection. There remains an imperative to develop diagnostic systems with fast turn-around times that are based on rapid molecular technologies in order to facilitate tailoring of therapy for mycobacterial lung disease [132]. While IGRAs enable identification of latent TB infection, they do not provide information on which patients are at risk of progression to active disease and interpreting the significance of borderline or indeterminate results can be complex [133]. The role of digital technologies in supporting treatment adherence in mycobacterial disease has been studied and combining data from such digital tools with personalised medicine data may yield new insights into likely disease outcomes. It will also be important to monitor therapeutic responses using validated patient-reported outcome measures [134]. Integrating artificial intelligence with personalised medicine techniques will have a transformational effect on clinicians' abilities to combine and process large volumes of genomic, clinical, microbiological and radiological data in order to individualise management plans [135]. This in turn will facilitate greater targeted monitoring of patients who are at highest risk of clinical deterioration through enhanced follow up or more intensive therapy. Ultimately a clear framework for the application of personalised medicine in mycobacterial pulmonary disease will be needed to facilitate its uptake in routine clinical practice.

Author Contributions: Conceptualization, K.K. and O.M.K.; writing-original draft preparation, K.K.; writing-review and editing, O.M.K. All authors have read and agreed to the published version of the manuscript.

Funding: K.K. and O.M.K. are supported by the National Institute for Health Research (NIHR) Imperial Biomedical Research Centre (BRC). K.K. is also supported by the Lee Family endowment to the Faculty of Medicine at Imperial College London. O.M.K. is also supported by the NIHR Health Protection Research Unit for Respiratory Infections. The views expressed are those of the authors and not necessarily those of the NIHR or the Department of Health and Social Care.

Acknowledgments: K.K. is an Imperial 4i Clinician Scientist at Imperial College London.

Conflicts of Interest: K.K. declares no conflict of interest. O.M.K. has received a study grant from Cepheid. 


\section{References}

1. World Health Organisation. Global Tuberculosis Report 2020. Available online: https://apps.who.int/iris/bitstream/handle/10 665/336069/9789240013131-eng.pdf (accessed on 12 August 2021).

2. Winthrop, K.L.; Marras, T.K.; Adjemian, J.; Zhang, H.; Wang, P.; Zhang, Q. Incidence and Prevalence of Nontuberculous Mycobacterial Lung Disease in a Large U.S. Managed Care Health Plan, 2008-2015. Ann. Am. Thorac. Soc. 2020, 17, 178-185. [CrossRef] [PubMed]

3. Park, S.C.; Kang, M.J.; Han, C.H.; Lee, S.M.; Kim, C.J.; Lee, J.M.; Kang, Y.A. Prevalence, incidence, and mortality of nontuberculous mycobacterial infection in Korea: A nationwide population-based study. BMC Pulm. Med. 2019, 19, 140. [CrossRef] [PubMed]

4. Walsh, C.M.; Gebert, M.J.; Delgado-Baquerizo, M.; Maestre, F.T.; Fierer, N. A Global Survey of Mycobacterial Diversity in Soil. Appl. Environ. Microbiol. 2019, 85, e01180-19. [CrossRef] [PubMed]

5. Kumar, K.; Kon, O.M. Diagnosis and treatment of tuberculosis: Latest developments and future priorities. Ann. Res. Hosp. 2017, 1, 37. [CrossRef]

6. Cowman, S.; van Ingen, J.; Griffith, D.E.; Loebinger, M.R. Non-tuberculous mycobacterial pulmonary disease. Eur. Respir. J. 2019, 54, 1900250. [CrossRef] [PubMed]

7. Lewinsohn, D.M.; Leonard, M.K.; LoBue, P.A.; Cohn, D.L.; Daley, C.L.; Desmond, E.; Keane, J.; Lewinsohn, D.A.; Loeffler, A.M.; Mazurek, G.H.; et al. Official American Thoracic Society/Infectious Diseases Society of America/Centers for Disease Control and Prevention Clinical Practice Guidelines: Diagnosis of Tuberculosis in Adults and Children. Clin. Infect. Dis. 2017, 64, 111-115. [CrossRef] [PubMed]

8. Daley, C.L.; Iaccarino, J.M.; Lange, C.; Cambau, E.; Wallace, R.J.; Andrejak, C.; Böttger, E.C.; Brozek, J.; Griffith, D.E.; Guglielmetti, L.; et al. Treatment of nontuberculous mycobacterial pulmonary disease: An official ATS/ERS/ESCMID/IDSA clinical practice guideline. Eur. Respir. J. 2020, 56, 2000535. [CrossRef] [PubMed]

9. Kumar, K.; Abubakar, I. Clinical implications of the global multidrug-resistant tuberculosis epidemic. Clin. Med. 2015, 15, s37-s42. [CrossRef] [PubMed]

10. Saxena, S.; Spaink, H.P.; Forn-Cuní, G. Drug Resistance in Nontuberculous Mycobacteria: Mechanisms and Models. Biology 2021, 10, 96. [CrossRef] [PubMed]

11. Official Journal of the European Union. Council Conclusions on Personalised Medicine for Patients. Available online: https: / / eur-lex.europa.eu/legal-content/EN/TXT/PDF/?uri=CELEX:52015XG1217(01)\&from=EN (accessed on 12 August 2021).

12. Vogenberg, F.R.; Isaacson Barash, C.; Pursel, M. Personalized medicine: Part 1: Evolution and development into theranostics. Pharm. Ther. 2010, 35, 560-576.

13. Thye, T.; Vannberg, F.O.; Wong, S.H.; Owusu-Dabo, E.; Osei, I.; Gyapong, J.; Sirugo, G.; Sisay-Joof, F.; Enimil, A.; Chinbuah, M.A.; et al. Genome-wide association analyses identifies a susceptibility locus for tuberculosis on chromosome 18q11.2. Nat. Genet. 2010, 42, 739-741. [CrossRef] [PubMed]

14. Miao, R.; Ge, H.; Xu, L.; Sun, Z.; Li, C.; Wang, R.; Ding, S.; Yang, C.; Xu, F. Genetic variants at $18 q 11.2$ and 8q24 identified by genome-wide association studies were not associated with pulmonary tuberculosis risk in Chinese population. Infect. Genet. Evol. 2016, 40, 214-218. [CrossRef] [PubMed]

15. Zheng, R.; Li, Z.; He, F.; Liu, H.; Chen, J.; Chen, J.; Xie, X.; Zhou, J.; Chen, H.; Wu, X.; et al. Genome-wide association study identifies two risk loci for tuberculosis in Han Chinese. Nat. Commun. 2018, 9, 4072. [CrossRef]

16. Thye, T.; Owusu-Dabo, E.; Vannberg, F.O.; van Crevel, R.; Curtis, J.; Sahiratmadja, E.; Balabanova, Y.; Ehmen, C.; Muntau, B.; Ruge, G.; et al. Common variants at 11 p13 are associated with susceptibility to tuberculosis. Nat. Genet. 2012, 44, 257-259. [CrossRef] [PubMed]

17. Chimusa, E.R.; Zaitlen, N.; Daya, M.; Möller, M.; van Helden, P.D.; Mulder, N.J.; Price, A.L.; Hoal, E.G. Genome-wide association study of ancestry-specific TB risk in the South African Coloured population. Hum. Mol. Genet. 2014, 23, 796-809. [CrossRef] [PubMed]

18. Quistrebert, J.; Orlova, M.; Kerner, G.; Ton, L.T.; Luong, N.T.; Danh, N.T.; Vincent, Q.B.; Jabot-Hanin, F.; Seeleuthner, Y.; Bustamante, J.; et al. Genome-wide association study of resistance to Mycobacterium tuberculosis infection identifies a locus at 10q26.2 in three distinct populations. PLoS Genet. 2021, 17, e1009392. [CrossRef] [PubMed]

19. Seshadri, C.; Sedaghat, N.; Campo, M.; Peterson, G.; Wells, R.D.; Olson, G.S.; Sherman, D.R.; Stein, C.M.; Mayanja-Kizza, H.; Shojaie, A.; et al. Transcriptional networks are associated with resistance to Mycobacterium tuberculosis infection. PLoS ONE 2017, 12, e0175844. [CrossRef] [PubMed]

20. Anderson, S.T.; Kaforou, M.; Brent, A.J.; Wright, V.J.; Banwell, C.M.; Chagaluka, G.; Crampin, A.C.; Dockrell, H.M.; French, N.; Hamilton, M.S.; et al. Diagnosis of childhood tuberculosis and host RNA expression in Africa. N. Engl. J. Med. 2014, 370, 1712-1723. [CrossRef] [PubMed]

21. Kaforou, M.; Wright, V.J.; Oni, T.; French, N.; Anderson, S.T.; Bangani, N.; Banwell, C.M.; Brent, A.J.; Crampin, A.C.; Dockrell, H.M.; et al. Detection of tuberculosis in HIV-infected and -uninfected African adults using whole blood RNA expression signatures: A case-control study. PLoS Med. 2013, 10, e1001538. [CrossRef] [PubMed]

22. Hoang, L.T.; Jain, P.; Pillay, T.D.; Tolosa-Wright, M.; Niazi, U.; Takwoingi, Y.; Halliday, A.; Berrocal-Almanza, L.C.; Deeks, J.J.; Beverley, P.; et al. Transcriptomic signatures for diagnosing tuberculosis in clinical practice: A prospective, multicentre cohort study. Lancet Infect. Dis. 2021, 21, 366-375. [CrossRef] 
23. Ziedalski, T.M.; Kao, P.N.; Henig, N.R.; Jacobs, S.S.; Ruoss, S.J. Prospective analysis of cystic fibrosis transmembrane regulator mutations in adults with bronchiectasis or pulmonary nontuberculous mycobacterial infection. Chest 2006, 130, 995-1002. [CrossRef] [PubMed]

24. Kim, R.D.; Greenberg, D.E.; Ehrmantraut, M.E.; Guide, S.V.; Ding, L.; Shea, Y.; Brown, M.R.; Chernick, M.; Steagall, W.K.; Glasgow, C.G.; et al. Pulmonary nontuberculous mycobacterial disease: Prospective study of a distinct preexisting syndrome. Am. J. Respir. Crit. Care Med. 2008, 178, 1066-1074. [CrossRef]

25. Colombo, R.E.; Hill, S.C.; Claypool, R.J.; Holland, S.M.; Olivier, K.N. Familial clustering of pulmonary nontuberculous mycobacterial disease. Chest 2010, 137, 629-634. [CrossRef] [PubMed]

26. Jang, M.; Kim, S.; Jeong, B.; Park, H.Y.; Jeon, K.; Kim, J.; Ki, C.; Koh, W. Association of CFTR gene variants with nontuberculous mycobacterial lung disease in a Korean population with a low prevalence of cystic fibrosis. J. Hum. Genet. 2013, 58, 298-303. [CrossRef]

27. Chen, Y.; Armstrong, D.A.; Salas, L.A.; Hazlett, H.F.; Nymon, A.B.; Dessaint, J.A.; Aridgides, D.S.; Mellinger, D.L.; Liu, X.; Christensen, B.C.; et al. Genome-wide DNA methylation profiling shows a distinct epigenetic signature associated with lung macrophages in cystic fibrosis. Clin. Epigenetics 2018, 10, 152. [CrossRef] [PubMed]

28. Zhang, S.; Shrestha, C.L.; Kopp, B.T. Cystic fibrosis transmembrane conductance regulator (CFTR) modulators have differential effects on cystic fibrosis macrophage function. Sci. Rep. 2018, 8, 17066. [CrossRef]

29. Bai, X.; Bai, A.; Honda, J.R.; Eichstaedt, C.; Musheyev, A.; Feng, Z.; Huitt, G.; Harbeck, R.; Kosmider, B.; Sandhaus, R.A.; et al. Alpha-1-Antitrypsin Enhances Primary Human Macrophage Immunity Against Non-tuberculous Mycobacteria. Front. Immunol. 2019, 10, 1417. [CrossRef] [PubMed]

30. Chan, E.D.; Kaminska, A.M.; Gill, W.; Chmura, K.; Feldman, N.E.; Bai, X.; Floyd, C.M.; Fulton, K.E.; Huitt, G.A.; Strand, M.J.; et al. Alpha-1-antitrypsin (AAT) anomalies are associated with lung disease due to rapidly growing mycobacteria and AAT inhibits Mycobacterium abscessus infection of macrophages. Scand. J. Infect. Dis. 2007, 39, 690-696. [CrossRef]

31. Witty, L.A.; Tapson, V.F.; Piantadosi, C.A. Isolation of mycobacteria in patients with pulmonary alveolar proteinosis. Medicine 1994, 73, 103-109. [CrossRef]

32. Abdul Rahman, J.A.; Moodley, Y.P.; Phillips, M.J. Pulmonary alveolar proteinosis associated with psoriasis and complicated by mycobacterial infection: Successful treatment with granulocyte-macrophage colony stimulating factor after a partial response to whole lung lavage. Respirology 2004, 9, 419-422. [CrossRef]

33. Sveinbjornsson, G.; Gudbjartsson, D.F.; Halldorsson, B.V.; Kristinsson, K.G.; Gottfredsson, M.; Barrett, J.C.; Gudmundsson, L.J.; Blondal, K.; Gylfason, A.; Gudjonsson, S.A.; et al. HLA class II sequence variants influence tuberculosis risk in populations of European ancestry. Nat. Genet. 2016, 48, 318-322. [CrossRef] [PubMed]

34. Lewis, S.J.; Baker, I.; Davey Smith, G. Meta-analysis of vitamin D receptor polymorphisms and pulmonary tuberculosis risk. Int. J. Tuberc. Lung Dis. 2005, 9, 1174-1177. [PubMed]

35. Huang, L.; Liu, C.; Liao, G.; Yang, X.; Tang, X.; Chen, J. Vitamin D Receptor Gene FokI Polymorphism Contributes to Increasing the Risk of Tuberculosis: An Update Meta-Analysis. Medicine 2015, 94, e2256. [CrossRef] [PubMed]

36. Gelder, C.M.; Hart, K.W.; Williams, O.M.; Lyons, E.; Welsh, K.I.; Campbell, I.A.; Marshall, S.E. Vitamin D receptor gene polymorphisms and susceptibility to Mycobacterium malmoense pulmonary disease. J. Infect. Dis. 2000, 181, $2099-2102$. [CrossRef] [PubMed]

37. Park, S.; Kim, E.J.; Lee, S.H.; Suh, G.Y.; Chung, M.P.; Kim, H.; Kwon, O.J.; Koh, W.J. Vitamin D-receptor polymorphisms and non-tuberculous mycobacterial lung disease in Korean patients. Int. J. Tuberc. Lung. Dis. 2008, 12, 698-700. [PubMed]

38. Koh, W.; Kwon, O.J.; Kim, E.J.; Lee, K.S.; Ki, C.; Kim, J.W. NRAMP1 gene polymorphism and susceptibility to nontuberculous mycobacterial lung diseases. Chest 2005, 128, 94-101. [CrossRef] [PubMed]

39. Becker, K.L.; Arts, P.; Jaeger, M.; Plantinga, T.S.; Gilissen, C.; van Laarhoven, A.; van Ingen, J.; Veltman, J.A.; Joosten, L.A.B.; Hoischen, A.; et al. MST1R mutation as a genetic cause of Lady Windermere syndrome. Eur. Respir. J. 2017, 49, 1601478. [CrossRef] [PubMed]

40. Sakamoto, O.; Iwama, A.; Amitani, R.; Takehara, T.; Yamaguchi, N.; Yamamoto, T.; Masuyama, K.; Yamanaka, T.; Ando, M.; Suda, T. Role of macrophage-stimulating protein and its receptor, RON tyrosine kinase, in ciliary motility. J. Clin. Investig. 1997, 99, 701-709. [CrossRef] [PubMed]

41. Rosain, J.; Kong, X.F.; Martinez-Barricarte, R.; Oleaga-Quintas, C.; Ramirez-Alejo, N.; Markle, J.; Okada, S.; Boisson-Dupuis, S.; Casanova, J.L.; Bustamante, J. Mendelian susceptibility to mycobacterial disease: 2014-2018 update. Immunol. Cell Biol. 2019, 97, 360-367. [CrossRef]

42. Kwon, Y.S.; Kim, E.J.; Lee, S.; Suh, G.Y.; Chung, M.P.; Kim, H.; Kwon, O.J.; Koh, W. Decreased cytokine production in patients with nontuberculous mycobacterial lung disease. Lung 2007, 185, 337-341. [CrossRef] [PubMed]

43. Cowman, S.A.; Jacob, J.; Hansell, D.M.; Kelleher, P.; Wilson, R.; Cookson, W.O.C.; Moffatt, M.F.; Loebinger, M.R. Whole-Blood Gene Expression in Pulmonary Nontuberculous Mycobacterial Infection. Am. J. Respir. Cell Mol. Biol. 2018, 58, 510-518. [CrossRef]

44. Remus, N.; El Baghdadi, J.; Fieschi, C.; Feinberg, J.; Quintin, T.; Chentoufi, M.; Schurr, E.; Benslimane, A.; Casanova, J.; Abel, L. Association of IL12RB1 polymorphisms with pulmonary tuberculosis in adults in Morocco. J. Infect. Dis. 2004, 190, 580-587. [CrossRef] [PubMed]

45. Park, H.Y.; Kwon, Y.S.; Ki, C.; Suh, G.Y.; Chung, M.P.; Kim, H.; Kwon, O.J.; Koh, W. Interleukin-12 receptor beta1 polymorphisms and nontuberculous mycobacterial lung diseases. Lung 2008, 186, 241. [CrossRef] 
46. Bermudez, L.E.; Young, L.S. Tumor necrosis factor, alone or in combination with IL-2, but not IFN-gamma, is associated with macrophage killing of Mycobacterium avium complex. J. Immunol. 1988, 140, 3006-3013. [PubMed]

47. Lutzky, V.P.; Ratnatunga, C.N.; Smith, D.J.; Kupz, A.; Doolan, D.L.; Reid, D.W.; Thomson, R.M.; Bell, S.C.; Miles, J.J. Anomalies in T Cell Function Are Associated With Individuals at Risk of Mycobacterium abscessus Complex Infection. Front. Immunol. 2018, 9, 1319. [CrossRef] [PubMed]

48. Shu, C.; Wang, J.; Wu, M.; Wu, C.; Lai, H.; Lee, L.; Chiang, B.; Yu, C. Attenuation of lymphocyte immune responses during Mycobacterium avium complex-induced lung disease due to increasing expression of programmed death-1 on lymphocytes. Sci. Rep. 2017, 7, 42004. [CrossRef] [PubMed]

49. Lim, A.; Allison, C.; Price, P.; Waterer, G. Susceptibility to pulmonary disease due to Mycobacterium avium-intracellulare complex may reflect low IL-17 and high IL-10 responses rather than Th1 deficiency. Clin. Immunol. 2010, 137, 296-302. [CrossRef]

50. Becker, K.L.; van Ingen, J.; Ten Oever, J.; Merkus, P.J.; Ferwerda, G.; Netea, M.G.; Magis-Escurra, C.; Reijers, M.H.; van de Veerdonk, F.L. Deficient interleukin-17 production in response to Mycobacterium abscessus in cystic fibrosis. Eur. Respir. J. 2016, 47, 990-993. [CrossRef] [PubMed]

51. Matsuyama, M.; Martins, A.J.; Shallom, S.; Kamenyeva, O.; Kashyap, A.; Sampaio, E.P.; Kabat, J.; Olivier, K.N.; Zelazny, A.M.; Tsang, J.S.; et al. Transcriptional Response of Respiratory Epithelium to Nontuberculous Mycobacteria. Am. J. Respir. Cell Mol. Biol. 2018, 58, 241-252. [CrossRef] [PubMed]

52. Pollara, G.; Turner, C.T.; Rosenheim, J.; Chandran, A.; Bell, L.C.K.; Khan, A.; Patel, A.; Peralta, L.F.; Folino, A.; Akarca, A.; et al. Exaggerated IL-17A activity in human in vivo recall responses discriminates active tuberculosis from latent infection and cured disease. Sci. Transl. Med. 2021, 13, eabg7673. [CrossRef] [PubMed]

53. Hsu, A.P.; McReynolds, L.J.; Holland, S.M. GATA2 deficiency. Curr. Opin. Allergy Clin. Immunol. 2015, 15, 104-109. [CrossRef]

54. Hsu, A.P.; Johnson, K.D.; Falcone, E.L.; Sanalkumar, R.; Sanchez, L.; Hickstein, D.D.; Cuellar-Rodriguez, J.; Lemieux, J.E.; Zerbe, C.S.; Bresnick, E.H.; et al. GATA2 haploinsufficiency caused by mutations in a conserved intronic element leads to MonoMAC syndrome. Blood 2013, 121, 3830-3837. [CrossRef] [PubMed]

55. Kumar, K.; Loebinger, M.R. Nontuberculous mycobacterial pulmonary disease: Clinical epidemiology, risk factors and diagnosis. Chest 2021, in press.

56. Kumar, K.; Shorten, R.J.; Capocci, S.; Solamalai, A.; Goodburn, A.; Cropley, I.; McHugh, T.D.; Lipman, M. The value of “inform and advise" guidance in a case of extensive tuberculosis transmission. J. Infect. 2013, 67, 158-160. [CrossRef]

57. Weyer, K.; Mirzayev, F.; Migliori, G.B.; Van Gemert, W.; D’Ambrosio, L.; Zignol, M.; Floyd, K.; Centis, R.; Cirillo, D.M.; Tortoli, E.; et al. Rapid molecular TB diagnosis: Evidence, policy making and global implementation of Xpert MTB/RIF. Eur. Respir. J. 2013, 42, 252-271. [CrossRef] [PubMed]

58. Telenti, A.; Imboden, P.; Marchesi, F.; Lowrie, D.; Cole, S.; Colston, M.J.; Matter, L.; Schopfer, K.; Bodmer, T. Detection of rifampicin-resistance mutations in Mycobacterium tuberculosis. Lancet 1993, 341, 647-650. [CrossRef]

59. Chakravorty, S.; Simmons, A.M.; Rowneki, M.; Parmar, H.; Cao, Y.; Ryan, J.; Banada, P.P.; Deshpande, S.; Shenai, S.; Gall, A.; et al. The New Xpert MTB/RIF Ultra: Improving Detection of Mycobacterium tuberculosis and Resistance to Rifampin in an Assay Suitable for Point-of-Care Testing. mBio 2017, 8, e00812-17. [CrossRef] [PubMed]

60. Cepheid. Xpert ${ }^{\circledR}$ MTB/RIF \& MTB/RIFUltra Product Comparison. Available online: https://p.widencdn.net/nvolny/CepheidXpert-MTB-RIF-Ultra-Comparison-Flyer-CE-IVD-3094-English (accessed on 12 August 2021).

61. Zifodya, J.S.; Kreniske, J.S.; Schiller, I.; Kohli, M.; Dendukuri, N.; Schumacher, S.G.; Ochodo, E.A.; Haraka, F.; Zwerling, A.A.; Pai, M.; et al. Xpert Ultra versus Xpert MTB/RIF for pulmonary tuberculosis and rifampicin resistance in adults with presumptive pulmonary tuberculosis. Cochrane Database Syst. Rev. 2021, 2, CD009593. [PubMed]

62. Cepheid. Xpert@MTB/XDR Datasheet. Available online: https://cepheid.widen.net/s/cwc24p8lcl (accessed on 12 August 2021).

63. Cao, Y.; Parmar, H.; Gaur, R.L.; Lieu, D.; Raghunath, S.; Via, N.; Battaglia, S.; Cirillo, D.M.; Denkinger, C.; Georghiou, S.; et al. Xpert MTB/XDR: A 10-Color Reflex Assay Suitable for Point-of-Care Settings To Detect Isoniazid, Fluoroquinolone, and SecondLine-Injectable-Drug Resistance Directly from Mycobacterium tuberculosis-Positive Sputum. J. Clin. Microbiol. 2021, 59, e02314-20. [CrossRef] [PubMed]

64. Georghiou, S.B.; Penn-Nicholson, A.; de Vos, M.; Macé, A.; Syrmis, M.W.; Jacob, K.; Mape, A.; Parmar, H.; Cao, Y.; Coulter, C.; et al. Analytical performance of the Xpert MTB/XDR ${ }^{\circledR}$ assay for tuberculosis and expanded resistance detection. Diagn. Microbiol. Infect. Dis. 2021, 101, 115397. [CrossRef]

65. Telenti, A.; Honoré, N.; Bernasconi, C.; March, J.; Ortega, A.; Heym, B.; Takiff, H.E.; Cole, S.T. Genotypic assessment of isoniazid and rifampin resistance in Mycobacterium tuberculosis: A blind study at reference laboratory level. J. Clin. Microbiol. 1997, 35, 719-723. [CrossRef] [PubMed]

66. Hain Lifescience. Rapid Diagnostics of Tuberculosis and Its Resistances. Available online: https://www.hain-lifescience.de/ uploadfiles/file/produkte/mikrobiologie/mykobakterien/tb_eng.pdf (accessed on 12 August 2021).

67. Nathavitharana, R.R.; Hillemann, D.; Schumacher, S.G.; Schlueter, B.; Ismail, N.; Omar, S.V.; Sikhondze, W.; Havumaki, J.; Valli, E.; Boehme, C.; et al. Multicenter Noninferiority Evaluation of Hain GenoType MTBDRplus Version 2 and Nipro NTM+MDRTB Line Probe Assays for Detection of Rifampin and Isoniazid Resistance. J. Clin. Microbiol. 2016, 54, 1624-1630. [CrossRef] [PubMed]

68. Nathavitharana, R.R.; Cudahy, P.G.T.; Schumacher, S.G.; Steingart, K.R.; Pai, M.; Denkinger, C.M. Accuracy of line probe assays for the diagnosis of pulmonary and multidrug-resistant tuberculosis: A systematic review and meta-analysis. Eur. Respir. J. 2017, 49, 1601075. [CrossRef] 
69. Javed, H.; Bakuła, Z.; Pleń, M.; Hashmi, H.J.; Tahir, Z.; Jamil, N.; Jagielski, T. Evaluation of Genotype MTBDRplus and MTBDRsl Assays for Rapid Detection of Drug Resistance in Extensively Drug-Resistant Mycobacterium tuberculosis Isolates in Pakistan. Front. Microbiol. 2018, 9, 2265. [CrossRef] [PubMed]

70. Nguyen, T.N.A.; Anton-Le Berre, V.; Bañuls, A.; Nguyen, T.V.A. Molecular Diagnosis of Drug-Resistant Tuberculosis; A Literature Review. Front. Microbiol. 2019, 10, 794. [CrossRef]

71. Makhado, N.A.; Matabane, E.; Faccin, M.; Pinçon, C.; Jouet, A.; Boutachkourt, F.; Goeminne, L.; Gaudin, C.; Maphalala, G.; Beckert, P.; et al. Outbreak of multidrug-resistant tuberculosis in South Africa undetected by WHO-endorsed commercial tests: An observational study. Lancet Infect. Dis. 2018, 18, 1350-1359. [CrossRef]

72. Hain Lifescience. GenoType NTM-DR. Available online: https://www.hain-lifescience.de/uploadfiles/file/produkte/ mikrobiologie/mykobakterien/gt-ntm-dr_eng.pdf (accessed on 12 August 2021).

73. Huh, H.J.; Kim, S.; Shim, H.J.; Kim, D.H.; Yoo, I.Y.; Kang, O.; Ki, C.; Shin, S.Y.; Jhun, B.W.; Shin, S.J.; et al. GenoType NTM-DR Performance Evaluation for Identification of Mycobacterium avium Complex and Mycobacterium abscessus and Determination of Clarithromycin and Amikacin Resistance. J. Clin. Microbiol. 2019, 57, e00516-19. [CrossRef] [PubMed]

74. Bouzinbi, N.; Marcy, O.; Bertolotti, T.; Chiron, R.; Bemer, P.; Pestel-Caron, M.; Peuchant, O.; Guet-Revillet, H.; Fangous, M.; Héry-Arnaud, G.; et al. Evaluation of the GenoType NTM-DR assay performance for the identification and molecular detection of antibiotic resistance in Mycobacterium abscessus complex. PLoS ONE 2020, 15, e0239146. [CrossRef] [PubMed]

75. Witney, A.A.; Cosgrove, C.A.; Arnold, A.; Hinds, J.; Stoker, N.G.; Butcher, P.D. Clinical use of whole genome sequencing for Mycobacterium tuberculosis. BMC Med. 2016, 14, 46. [CrossRef] [PubMed]

76. Pankhurst, L.J.; Del Ojo Elias, C.; Votintseva, A.A.; Walker, T.M.; Cole, K.; Davies, J.; Fermont, J.M.; Gascoyne-Binzi, D.M.; Kohl, T.A.; Kong, C.; et al. Rapid, comprehensive, and affordable mycobacterial diagnosis with whole-genome sequencing: A prospective study. Lancet Respir. Med. 2016, 4, 49-58. [CrossRef]

77. Doyle, R.M.; Burgess, C.; Williams, R.; Gorton, R.; Booth, H.; Brown, J.; Bryant, J.M.; Chan, J.; Creer, D.; Holdstock, J.; et al. Direct Whole-Genome Sequencing of Sputum Accurately Identifies Drug-Resistant Mycobacterium tuberculosis Faster than MGIT Culture Sequencing. J. Clin. Microbiol. 2018, 56, e00666-18. [CrossRef] [PubMed]

78. Feuerriegel, S.; Kohl, T.A.; Utpatel, C.; Andres, S.; Maurer, F.P.; Heyckendorf, J.; Jouet, A.; Badalato, N.; Foray, L.; Fouad Kamara, R.; et al. Rapid genomic first- and second-line drug resistance prediction from clinical Mycobacterium tuberculosis specimens using Deeplex-MycTB. Eur. Respir. J. 2021, 57, 2001796. [CrossRef] [PubMed]

79. Fedrizzi, T.; Meehan, C.J.; Grottola, A.; Giacobazzi, E.; Fregni Serpini, G.; Tagliazucchi, S.; Fabio, A.; Bettua, C.; Bertorelli, R.; De Sanctis, V.; et al. Genomic characterization of Nontuberculous Mycobacteria. Sci. Rep. 2017, 7, 45258. [CrossRef] [PubMed]

80. Bryant, J.M.; Grogono, D.M.; Greaves, D.; Foweraker, J.; Roddick, I.; Inns, T.; Reacher, M.; Haworth, C.S.; Curran, M.D.; Harris, S.R.; et al. Whole-genome sequencing to identify transmission of Mycobacterium abscessus between patients with cystic fibrosis: A retrospective cohort study. Lancet 2013, 381, 1551-1560. [CrossRef]

81. Yoon, J.; Kim, T.S.; Kim, J.; Yim, J. Whole genome sequencing of Nontuberculous Mycobacterium (NTM) isolates from sputum specimens of co-habiting patients with NTM pulmonary disease and NTM isolates from their environment. BMC Genomics 2020, 21, 322. [CrossRef] [PubMed]

82. Khieu, V.; Ananta, P.; Kaewprasert, O.; Laohaviroj, M.; Namwat, W.; Faksri, K. Whole-Genome Sequencing Analysis to Identify Infection with Multiple Species of Nontuberculous Mycobacteria. Pathogens 2021, 10, 879. [CrossRef]

83. Joao, I.; Cristovao, P.; Antunes, L.; Nunes, B.; Jordao, L. Identification of nontuberculous mycobacteria by partial gene sequencing and public databases. Int. J. Mycobacteriol. 2014, 3, 144-151. [CrossRef] [PubMed]

84. Cowman, S.A.; James, P.; Wilson, R.; Cookson, W.O.C.; Moffatt, M.F.; Loebinger, M.R. Profiling mycobacterial communities in pulmonary nontuberculous mycobacterial disease. PLoS ONE 2018, 13, e0208018. [CrossRef] [PubMed]

85. Hallstrand, T.S.; Ochs, H.D.; Zhu, Q.; Liles, W.C. Inhaled IFN-gamma for persistent nontuberculous mycobacterial pulmonary disease due to functional IFN-gamma deficiency. Eur. Respir. J. 2004, 24, 367-370. [CrossRef] [PubMed]

86. Remiszewski, P.; Roszkowska-Sliz, B.; Winek, J.; Chapgier, A.; Feinberg, J.; Langfort, R.; Bestry, I.; Augustynowicz-Kopeć, E.; Ptak, J.; Casanova, J.; et al. Disseminated Mycobacterium avium infection in a 20-year-old female with partial recessive IFNgammaR1 deficiency. Respiration 2006, 73, 375-378. [CrossRef] [PubMed]

87. Gao, X.F.; Yang, Z.W.; Li, J. Adjunctive therapy with interferon-gamma for the treatment of pulmonary tuberculosis: A systematic review. Int. J. Infect. Dis. 2011, 15, e594-e600. [CrossRef]

88. Koizumi, Y.; Sakagami, T.; Nishiyama, N.; Hirai, J.; Hayashi, Y.; Asai, N.; Yamagishi, Y.; Kato, H.; Hagihara, M.; Sakanashi, D.; et al Rituximab Restores IFN- $\gamma$-STAT1 Function and Ameliorates Disseminated Mycobacterium avium Infection in a Patient with Anti-Interferon- $\gamma$ Autoantibody. J. Clin. Immunol. 2017, 37, 644-649. [CrossRef] [PubMed]

89. Browne, S.K.; Zaman, R.; Sampaio, E.P.; Jutivorakool, K.; Rosen, L.B.; Ding, L.; Pancholi, M.J.; Yang, L.M.; Priel, D.L.; Uzel, G.; et al. Anti-CD20 (rituximab) therapy for anti-IFN- $\gamma$ autoantibody-associated nontuberculous mycobacterial infection. Blood 2012, 119, 3933-3939. [CrossRef] [PubMed]

90. Chetchotisakd, P.; Anunnatsiri, S.; Nanagara, R.; Nithichanon, A.; Lertmemongkolchai, G. Intravenous Cyclophosphamide Therapy for Anti-IFN-Gamma Autoantibody-Associated Mycobacterium abscessus Infection. J. Immunol. Res. 2018, 2018, 6473629. [CrossRef]

91. Scott, J.P.; Ji, Y.; Kannan, M.; Wylam, M.E. Inhaled granulocyte-macrophage colony-stimulating factor for Mycobacterium abscessus in cystic fibrosis. Eur. Respir. J. 2018, 51, 1702127. [CrossRef] [PubMed] 
92. Pedral-Sampaio, D.B.; Netto, E.M.; Brites, C.; Bandeira, A.C.; Guerra, C.; Barberin, M.G.; Badaró, R. Use of Rhu-GM-CSF in pulmonary tuberculosis patients: Results of a randomized clinical trial. Braz. J. Infect. Dis. 2003, 7, 245-252. [CrossRef] [PubMed]

93. Bentur, L.; Gur, M.; Ashkenazi, M.; Livnat-Levanon, G.; Mizrahi, M.; Tal, A.; Ghaffari, A.; Geffen, Y.; Aviram, M.; Efrati, O. Pilot study to test inhaled nitric oxide in cystic fibrosis patients with refractory Mycobacterium abscessus lung infection. J. Cyst. Fibros. 2020, 19, 225-231. [CrossRef] [PubMed]

94. Dedrick, R.M.; Guerrero-Bustamante, C.A.; Garlena, R.A.; Russell, D.A.; Ford, K.; Harris, K.; Gilmour, K.C.; Soothill, J.; Jacobs-Sera, D.; Schooley, R.T.; et al. Engineered bacteriophages for treatment of a patient with a disseminated drug-resistant Mycobacterium abscessus. Nat. Med. 2019, 25, 730-733. [CrossRef] [PubMed]

95. Kolloli, A.; Subbian, S. Host-Directed Therapeutic Strategies for Tuberculosis. Front. Med. 2017, 4, 171. [CrossRef] [PubMed]

96. Crilly, N.P.; Ayeh, S.K.; Karakousis, P.C. The New Frontier of Host-Directed Therapies for Mycobacterium avium Complex. Front. Immunol. 2021, 11, 623119. [CrossRef] [PubMed]

97. Kilinç, G.; Saris, A.; Ottenhoff, T.H.M.; Haks, M.C. Host-directed therapy to combat mycobacterial infections. Immunol. Rev. 2021, 301, 62-83. [CrossRef] [PubMed]

98. Kang, J.S.; Lee, M.H. Overview of therapeutic drug monitoring. Korean J. Intern. Med. 2009, 24, 1-10. [CrossRef] [PubMed]

99. Sotgiu, G.; Alffenaar, J.C.; Centis, R.; D'Ambrosio, L.; Spanevello, A.; Piana, A.; Migliori, G.B. Therapeutic drug monitoring: How to improve drug dosage and patient safety in tuberculosis treatment. Int. J. Infect. Dis. 2015, 32, 101-104. [CrossRef] [PubMed]

100. Heysell, S.K.; Moore, J.L.; Keller, S.J.; Houpt, E.R. Therapeutic drug monitoring for slow response to tuberculosis treatment in a state control program, Virginia, USA. Emerg. Infect. Dis. 2010, 16, 1546-1553. [CrossRef]

101. Azuma, J.; Ohno, M.; Kubota, R.; Yokota, S.; Nagai, T.; Tsuyuguchi, K.; Okuda, Y.; Takashima, T.; Kamimura, S.; Fujio, Y.; et al. NAT2 genotype guided regimen reduces isoniazid-induced liver injury and early treatment failure in the 6-month four-drug standard treatment of tuberculosis: A randomized controlled trial for pharmacogenetics-based therapy. Eur. J. Clin. Pharmacol. 2013, 69, 1091-1101. [CrossRef] [PubMed]

102. Verma, R.; Patil, S.; Zhang, N.; Moreira, F.M.F.; Vitorio, M.T.; Santos, A.d.S.; Wallace, E.; Gnanashanmugam, D.; Persing, D.; Savic, R.; et al. A Rapid Pharmacogenomic Assay to Detect NAT2 Polymorphisms and Guide Isoniazid Dosing for Tuberculosis Treatment. Am. J. Respir. Crit. Care Med. 2021, in press. [CrossRef] [PubMed]

103. Kumar, K.; McHugh, T.D.; Lipman, M. Fluoroquinolones for treating tuberculosis. Clin. Pharm. 2017, 9, $142-149$.

104. Van den Elsen, S.H.; Sturkenboom, M.G.; Akkerman, O.; Barkane, L.; Bruchfeld, J.; Eather, G.; Heysell, S.K.; Hurevich, H.; Kuksa, L.; Kunst, H.; et al. Prospective evaluation of improving fluoroquinolone exposure using centralised therapeutic drug monitoring (TDM) in patients with tuberculosis (PERFECT): A study protocol of a prospective multicentre cohort study. BMJ Open 2020, 10, e035350. [CrossRef]

105. Van Altena, R.; Dijkstra, J.A.; van der Meer, M.E.; Borjas Howard, J.F.; Kosterink, J.G.W.; van Soolingen, D.; van der Werf, T.S.; Alffenaar, J.W.C. Reduced Chance of Hearing Loss Associated with Therapeutic Drug Monitoring of Aminoglycosides in the Treatment of Multidrug-Resistant Tuberculosis. Antimicrob. Agents Chemother. 2017, 61, e01400-16. [CrossRef] [PubMed]

106. Sabur, N.F.; Brar, M.S.; Wu, L.; Brode, S.K. Low-dose amikacin in the treatment of Multidrug-resistant Tuberculosis (MDR-TB). BMC Infect. Dis. 2021, 21, 254. [CrossRef] [PubMed]

107. Bolhuis, M.S.; van der Werf, T.S.; Kerstjens, H.A.M.; de Lange, W.C.; Alffenaar, J.W.C.; Akkerman, O.W. Treatment of multidrugresistant tuberculosis using therapeutic drug monitoring: First experiences with sub-300 mg linezolid dosages using in-house made capsules. Eur. Respir. J. 2019, 54, 1900580. [CrossRef] [PubMed]

108. Vu, D.H.; Bolhuis, M.S.; Koster, R.A.; Greijdanus, B.; de Lange, W.C.M.; van Altena, R.; Brouwers, J.R.B.J.; Uges, D.R.A.; Alffenaar, J.W.C. Dried blood spot analysis for therapeutic drug monitoring of linezolid in patients with multidrug-resistant tuberculosis. Antimicrob. Agents Chemother. 2012, 56, 5758-5763. [CrossRef] [PubMed]

109. Vu, D.H.; Koster, R.A.; Bolhuis, M.S.; Greijdanus, B.; Altena, R.V.; Nguyen, D.H.; Brouwers, J.R.B.J.; Uges, D.R.A.; Alffenaar, J.W.C. Simultaneous determination of rifampicin, clarithromycin and their metabolites in dried blood spots using LC-MS/MS. Talanta 2014, 121, 9-17. [CrossRef] [PubMed]

110. Gygli, S.M.; Keller, P.M.; Ballif, M.; Blöchliger, N.; Hömke, R.; Reinhard, M.; Loiseau, C.; Ritter, C.; Sander, P.; Borrell, S.; et al. Whole-Genome Sequencing for Drug Resistance Profile Prediction in Mycobacterium tuberculosis. Antimicrob. Agents Chemother. 2019, 63, e02175-18. [CrossRef]

111. Ruesen, C.; Riza, A.L.; Florescu, A.; Chaidir, L.; Editoiu, C.; Aalders, N.; Nicolosu, D.; Grecu, V.; Ioana, M.; van Crevel, R.; et al. Linking minimum inhibitory concentrations to whole genome sequence-predicted drug resistance in Mycobacterium tuberculosis strains from Romania. Sci. Rep. 2018, 8, 9676. [CrossRef] [PubMed]

112. Nonghanphithak, D.; Kaewprasert, O.; Chaiyachat, P.; Reechaipichitkul, W.; Chaiprasert, A.; Faksri, K. Whole-genome sequence analysis and comparisons between drug-resistance mutations and minimum inhibitory concentrations of Mycobacterium tuberculosis isolates causing M/XDR-TB. PLoS ONE 2020, 15, e0244829. [CrossRef] [PubMed]

113. Wang, Z.; Arat, S.; Magid-Slav, M.; Brown, J.R. Meta-analysis of human gene expression in response to Mycobacterium tuberculosis infection reveals potential therapeutic targets. BMC Syst. Biol. 2018, 12, 3. [CrossRef]

114. Luo, J.; Zhang, M.; Yan, B.; Li, F.; Guan, S.; Chang, K.; Jiang, W.; Xu, H.; Yuan, T.; Chen, M.; et al. Diagnostic performance of plasma cytokine biosignature combination and MCP-1 as individual biomarkers for differentiating stages Mycobacterium tuberculosis infection. J. Infect. 2019, 78, 281-291. [CrossRef] [PubMed] 
115. Halliday, A.; Masonou, T.; Tolosa-Wright, M.R.; Guo, Y.; Hoang, L.; Parker, R.; Boakye, A.; Takwoingi, Y.; Badhan, A.; Jain, P.; et al. Defining the Role of Cellular Immune Signatures in Diagnostic Evaluation of Suspected Tuberculosis. J. Infect. Dis. 2021, in press. [CrossRef] [PubMed]

116. Sweeney, T.E.; Braviak, L.; Tato, C.M.; Khatri, P. Genome-wide expression for diagnosis of pulmonary tuberculosis: A multicohort analysis. Lancet Respir. Med. 2016, 4, 213-224. [CrossRef]

117. Halliday, A.; Jain, P.; Hoang, L.; Parker, R.; Tolosa-Wright, M.; Masonou, T.; Green, N.; Boakye, A.; Takwoingi, Y.; Hamilton, S.; et al. New technologies for diagnosing active TB: The VANTDET diagnostic accuracy study. Effic. Mech. Eval. 2021, 8, 1-160. [CrossRef]

118. Zak, D.E.; Penn-Nicholson, A.; Scriba, T.J.; Thompson, E.; Suliman, S.; Amon, L.M.; Mahomed, H.; Erasmus, M.; Whatney, W.; Hussey, G.D.; et al. A blood RNA signature for tuberculosis disease risk: A prospective cohort study. Lancet 2016, 387, $2312-2322$. [CrossRef]

119. Scriba, T.J.; Penn-Nicholson, A.; Shankar, S.; Hraha, T.; Thompson, E.G.; Sterling, D.; Nemes, E.; Darboe, F.; Suliman, S.; Amon, L.M.; et al. Sequential inflammatory processes define human progression from M. tuberculosis infection to tuberculosis disease. PLoS Pathog. 2017, 13, e1006687. [CrossRef] [PubMed]

120. Berry, M.P.R.; Graham, C.M.; McNab, F.W.; Xu, Z.; Bloch, S.A.A.; Oni, T.; Wilkinson, K.A.; Banchereau, R.; Skinner, J.; Wilkinson, R.J.; et al. An interferon-inducible neutrophil-driven blood transcriptional signature in human tuberculosis. $\mathrm{Na}-$ ture 2010, 466, 973-977. [CrossRef]

121. Bloom, C.I.; Graham, C.M.; Berry, M.P.R.; Wilkinson, K.A.; Oni, T.; Rozakeas, F.; Xu, Z.; Rossello-Urgell, J.; Chaussabel, D.; Banchereau, J.; et al. Detectable changes in the blood transcriptome are present after two weeks of antituberculosis therapy. PLoS ONE 2012, 7, e46191. [CrossRef] [PubMed]

122. Sigal, G.B.; Segal, M.R.; Mathew, A.; Jarlsberg, L.; Wang, M.; Barbero, S.; Small, N.; Haynesworth, K.; Davis, J.L.; Weiner, M.; et al. Biomarkers of Tuberculosis Severity and Treatment Effect: A Directed Screen of 70 Host Markers in a Randomized Clinical Trial. EBioMedicine 2017, 25, 112-121. [CrossRef] [PubMed]

123. Ahmed, M.I.M.; Ntinginya, N.E.; Kibiki, G.; Mtafya, B.A.; Semvua, H.; Mpagama, S.; Mtabho, C.; Saathoff, E.; Held, K.; Loose, R.; et al. Phenotypic Changes on Mycobacterium Tuberculosis-Specific CD4 T Cells as Surrogate Markers for Tuberculosis Treatment Efficacy. Front. Immunol. 2018, 9, 2247. [CrossRef]

124. Lee, M.; Tsai, C.; Wang, W.; Chuang, T.; Yang, C.; Chang, L.; Lin, C.; Wang, J.; Shu, C.; Lee, L.; et al. Plasma Biomarkers Can Predict Treatment Response in Tuberculosis Patients: A Prospective Observational Study. Medicine 2015, 94, e1628. [CrossRef]

125. Peter, J.G.; Zijenah, L.S.; Chanda, D.; Clowes, P.; Lesosky, M.; Gina, P.; Mehta, N.; Calligaro, G.; Lombard, C.J.; Kadzirange, G.; et al. Effect on mortality of point-of-care, urine-based lipoarabinomannan testing to guide tuberculosis treatment initiation in HIVpositive hospital inpatients: A pragmatic, parallel-group, multicountry, open-label, randomised controlled trial. Lancet 2016, 387, 1187-1197. [CrossRef]

126. Drain, P.K.; Gounder, L.; Grobler, A.; Sahid, F.; Bassett, I.V.; Moosa, M.S. Urine lipoarabinomannan to monitor antituberculosis therapy response and predict mortality in an HIV-endemic region: A prospective cohort study. BMJ Open 2015, 5, e006833. [CrossRef] [PubMed]

127. Danho, R.; Schildkraut, J.A.; Zweijpfenning, S.M.H.; Svensson, E.M.; Pennings, L.J.; Kuipers, S.; Wertheim, H.F.L.; Boeree, M.J.; Hoefsloot, W.; van Ingen, J. MGIT time-to-positivity can serve as an early biomarker of treatment response in Mycobacterium avium complex pulmonary disease. Chest 2021, in press. [CrossRef] [PubMed]

128. Kitada, S.; Maekura, R.; Yoshimura, K.; Miki, K.; Miki, M.; Oshitani, Y.; Nishida, K.; Sawa, N.; Mori, M.; Kobayashi, K. Levels of Antibody against Glycopeptidolipid Core as a Marker for Monitoring Treatment Response in Mycobacterium avium Complex Pulmonary Disease: A Prospective Cohort Study. J. Clin. Microbiol. 2017, 55, 884-892. [CrossRef] [PubMed]

129. Kim, S.Y.; Koh, W.J.; Park, H.Y.; Jeon, K.; Kwon, O.J.; Cho, S.N.; Shin, S.J. Changes in serum immunomolecules during antibiotic therapy for Mycobacterium avium complex lung disease. Clin. Exp. Immunol. 2014, 176, 93-101. [CrossRef] [PubMed]

130. Han, S.A.; Jhun, B.W.; Kim, S.; Moon, S.M.; Yang, B.; Kwon, O.J.; Daley, C.L.; Shin, S.J.; Koh, W. miRNA Expression Profiles and Potential as Biomarkers in Nontuberculous Mycobacterial Pulmonary Disease. Sci. Rep. 2020, 10, 3178. [CrossRef] [PubMed]

131. Heyckendorf, J.; Marwitz, S.; Reimann, M.; Avsar, K.; DiNardo, A.R.; Günther, G.; Hoelscher, M.; Ibraim, E.; Kalsdorf, B.; Kaufmann, S.H.E.; et al. Prediction of anti-tuberculosis treatment duration based on a 22-gene transcriptomic model. Eur. Respir. J. 2021, 58, 2003492. [CrossRef] [PubMed]

132. Gröschel, M.I.; Walker, T.M.; van der Werf, T.S.; Lange, C.; Niemann, S.; Merker, M. Pathogen-based precision medicine for drug-resistant tuberculosis. PLoS Pathog. 2018, 14, e1007297. [CrossRef]

133. Brown, J.; Kumar, K.; Reading, J.; Harvey, J.; Murthy, S.; Capocci, S.; Hopkins, S.; Seneviratne, S.; Cropley, I.; Lipman, M. Frequency and significance of indeterminate and borderline Quantiferon Gold TB IGRA results. Eur. Respir. J. 2017, 50, 1701267. [CrossRef]

134. Loebinger, M.R.; Birring, S.S. Patient reported outcomes for non-tuberculous mycobacterial disease. Eur. Respir. J. 2020, 55, 1902204. [CrossRef] [PubMed]

135. Johnson, K.B.; Wei, W.; Weeraratne, D.; Frisse, M.E.; Misulis, K.; Rhee, K.; Zhao, J.; Snowdon, J.L. Precision Medicine, AI, and the Future of Personalized Health Care. Clin. Transl. Sci. 2021, 14, 86-93. [CrossRef] 